\title{
EVALUATION OF IN VITRO ANTICANCER ACTIVITY OF AERIAL PARTS OF AVICENNIA ALBA PLANT METHANOLIC EXTRACT AGAINST HELA AND MCF-7 CELL LINES
}

\author{
RA ZERUBABEL MICHAEL *
}

Centre for Biotechnology, Department of Chemical Engineering, AUCE (A), Andhra University, Visakhapatnam, Andhra Pradesh, India. Email: michaelzerubabel@gmail.com

Received: 03 January 2021, Revised and Accepted: 14 April 2021

\section{ABSTRACT}

Objective: The current study emphasizes the effects of stem and leaf methanolic extract of mangrove plant Avicennia alba on human tumor cell lines HeLa and MCF-7.

Method: The collected mangrove plant sample was subjected to extraction with methanol and screened for anticancer activity according to 3-(4,5-dimethythiazol- 2-yl)-2,5-diphenyl tetrazolium bromide (MTT) assay method. The ability of the plant extract to inhibit the proliferation of HeLa and MCF-7 cell lines procured from NCCS Pune was compared parallel to inhibitory effect of standard drug Cisplatin. The spectrophotometric optical densities obtained were plotted on graph and consecutive data were obtained to depict the inhibitory effect and IC ${ }_{50}$ values. The histopathology studies were also done for a clear insight to understand the depth of inhibition microscopically.

Results: The MTT assay performed illustrates the plant samples with different concentrations $(10,20,25,30$, and $50 \mu \mathrm{g})$ showed significant inhibitory effect on comparison with the standard drug Cisplatin. The $\mathrm{IC}_{50}$ values and the inhibitory OD values elucidate effective projection of plant as a potential source of anticancer activity based on comparative study. The histopathology studies revealed an insight to a clearer picture of how the cells growth was controlled. It was found that the methanolic extract of $A$. alba exhibited more activity against HeLa cell lines than MCF-7 cell lines.

Conclusion: The synergistic effect of various phytochemicals present in the methanolic plant extract played a significant role in establishing the plant as a significant anticancer source.

Keywords: Avicennia alba, Cisplatin, HeLa cell lines, MCF-7cell lines, 3-(4,5-dimethythiazol- 2-yl)-2,5-diphenyl tetrazolium bromide assay.

(C) 2021 The Authors. Published by Innovare Academic Sciences Pvt Ltd. This is an open access article under the CC BY license (http://creativecommons.org/ licenses/by/4.0/) DOI: http://dx.doi.org/10.22159/ajpcr.2021v14i6.41259. Journal homepage: https://innovareacademics.in/journals/index.php/ajpcr

\section{INTRODUCTION}

Since medieval times, plants have been the major source of medicines for the treatment of various diseases. At present, plants remain an integral part of the healthcare in different countries including developed countries. According to the World Health Organization (WHO), $80 \%$ of the people living in rural areas depend on the medicinal plants as primary healthcare system [1,2]. Medicinal plants possess an important position in the drug discovery and many modern drugs have their origin in traditional medicine of different cultures. Hence, regardless of the advantages of the synthetic and combinatorial chemistry as well as molecular modeling, medicinal plants remain an important source of new drugs, new drug leads, and new chemical entities [3,4]. It was reported that out of over 800 new chemical entities introduced between 1981 and 2002 nearly the half were natural products and semi-synthetic natural products [5]. Cancer is a multistep disease developed by environmental, physical, chemical, metabolic, and genetic factors. Cancer is a disease which involves cells growing out of control resulting in tissue growth regulation failure. For a normal cell to transform in to cancer cell, the genes which regulate cell growth and differentiation must be altered [6]. The causes of cancer are diverse, complex, and partially understood. Many things are known to increase the risk of cancer, including tobacco use, dietary factors, certain infections, and exposure to pollutants [7]. Conventional treatment of cancer includes interventions such as psychological support, surgery, radiotherapy, and chemotherapy [8]. At present, the most frequently used cancer chemotherapy includes natural anticancer agents. However, due to increasing rate of mortality associated with caner and adverse or toxic side effects of cancer chemotherapy and radiation therapy has greatly facilitated efforts in the search for more effective and novel secondary metabolites as anticancer lead molecules for some time. The plant extracts have conventionally been screened for such findings. Herbal medicine constitutes a major substitute for cancer prevention and treatment in anomalous countries around the globe. The effect of plant extracts as anticancer was widely studied due to their low toxicity and side effects. Due to the aforementioned concerns, such studies investigating medicinal plants have been steadily held with interests. At present, the number of plants reported to possess anticancer properties are more than $3000[9,10]$. The mangroves exist under stressful conditions such as extreme environments, high concentration of moisture, high and low tides of water and abundant living microorganisms, and insects. They thrive in a very peculiar environment and serve as a bridging ecosystem between freshwater and marine systems. These have imposed several modifications in these plants. They possess modifications to establish water and salt economy. There are modifications or alterations in other physiological processes such as carbohydrate metabolism or polyphenol synthesis and due to these reasons; they possess chemical compounds which protect them from these destructive elements. The genus Avicennia is a pioneer group of dominant mangrove species with potential medicinal values. Avicennia alba is a type of tropical mangrove plant and classified to the family Acanthaceae. The plant is found in south and south east Asia, the islands of the south Pacific Ocean and Australia [11].

It is a native of India and is distributed in coastal regions of south Indian mangrove forests [12]. Its widespread root system with large numbers of pneumatophores helps to stabilize new deposits of sediment and is highly tolerant to saline environment [13]. It is used for the treatment of several types of diseases such as sexual disorders, scabies, rheumatism, paralysis, asthma, and snake-bites and ulcer. The resin of seeds and leaves is used in traditional medicine as contraceptive. Various studies have reported that the extract of $A$. alba shows broad range of biological activities, such as anticancer, anti-inflammatory, antimicrobial, antidiarrheal, and analgesic. The previous phytochemical studies on the plant have reported in the isolation of steroids, triterpenes, saponins, flavonoids, alkaloids, and tannins. Three naphthoquinones and their analogs such 
as avicequinone- $\mathrm{A}$, avicequinone- $\mathrm{B}$, and avicequinone- $\mathrm{C}$, and avicenol- $\mathrm{A}$, avicenol-B, and avicenol-C, respectively, were isolated from stem bark of $A$. alba. Conventionally, more than 100 numbers of mangroves and mangrove-associated plant used for the treatment of cancer have been reported, but only a very few number of plants are evaluated and reported scientifically. Recently, the medicinal value of mangroves and associated plants persist to provide priceless therapeutic agents, both in modern medicines and in traditional systems [14]. The present study deals with the anticancer activity of $A$. alba on HeLa and MCF-7 cell lines using 3-(4,5-dimethythiazol- 2-yl)-2,5-diphenyl tetrazolium bromide (MTT) assay against HeLa and MCF-7 cell lines. Colorimetric assay (MTT) is mainly useful in determination of cellular proliferation, viability, and activation. The microscopic observations of the \% cell inhibition of HeLa and MCF-7 were compared to Standard Cisplatin (HeLa and MCF-7 cell lines).

\section{MATERIALS AND METHODS}

\section{Collection of plant materials}

The stem and leaves of $A$. alba were collected during the month of August 2014 from korangi mangrove forests, Kakinada, Andhra Pradesh.

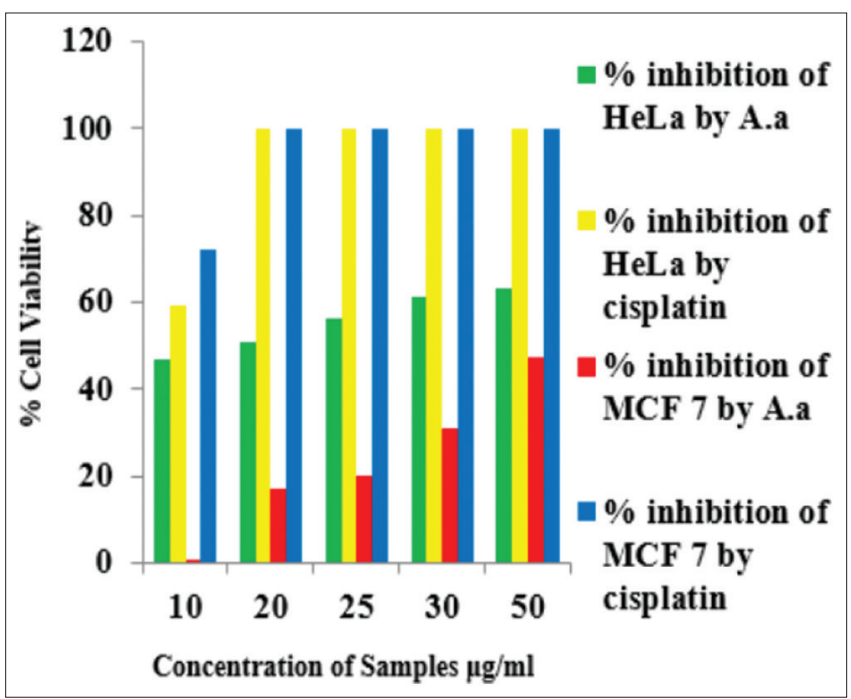

Fig. 1: Comparison of Anticancer activity of Standard Cisplatin with Methanolic extracts of Avicennia alba against HELA and MCF7 cell lines

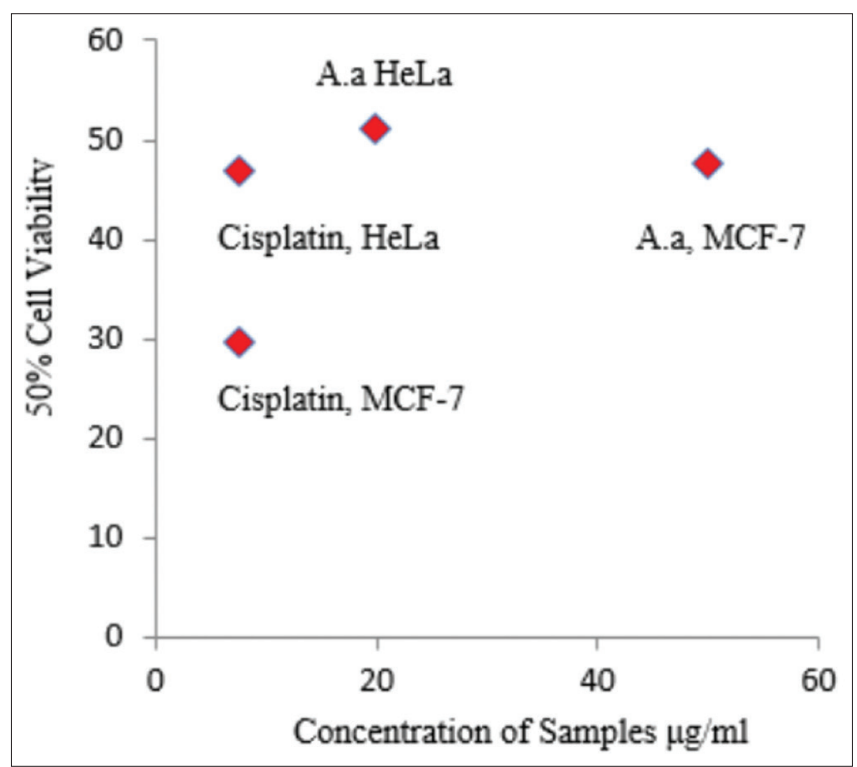

Fig. 2: Comparison of IC50 of Hela and MCF-7 of A.a and standard cisplatin
The collected plant material was identified and its authenticity was confirmed by Prof G.Mohana Narasimharao, Department of Botany, College of Science and Technology, Andhra University, Visakhapatnam. The herbarium voucher specimen has been kept in Pharmacognosy and phytochemistry laboratory, Andhra University for further reference. Freshly collected plant material was cleaned to remove adhering dust by washing under running water and then dried under shade. The dried sample was powdered weighing about $4 \mathrm{~kg}$ and used for further studies.

\section{Solvent extraction}

The air dried, powdered stem, and leaves (1 kg) was macerated using methanol ( $3 \mathrm{~L}$ ) for a period of 3 days in room temperature and was filtered using No.1 Whatman filter paper. The extract was then vacuum dried in rotary vacuum evaporator and used for further studies.

\section{Cell lines and culture conditions}

The cell line used for the study were HeLa and MCF-7, human procured from NCCS, Pune. The cell lines were maintained in 96 wells micro titer plate containing MEM media supplemented with $10 \%$ heat inactivated fetal calf serum, containing $5 \%$ of mixture of Gentamicin (10 ug), Penicillin (100 Units $/ \mathrm{ml}$ ), and Streptomycin $(100 \mu \mathrm{g} / \mathrm{ml})$ in the presence of $5 \% \mathrm{CO}_{2}$ at $37^{\circ} \mathrm{C}$ for 48-72 h.

\section{In vitro cytotoxicity [15]}

Common basic steps that are present in in vitro cytotoxic activity include: Isolation of cells, incubation of cell lines with drug for appropriate period of time, assessment of cell survival, and interpretation of result. This is a colorimetric assay [16] that measures the reduction of yellow MTT by mitochondrial succinate dehydrogenase. The MTT enters the cells and passes into the mitochondria where it is reduced to an insoluble, colored (dark purple) formazan product. The cells are then solubilized with an organic solvent (e.g. dimethyl sulfoxide [DMSO], Isopropanol) and the released, solubilized formazan reagent is measured spectrophotometrically. Since reduction of MTT can only occur in metabolically active cells, the level of activity is a measure of the viability of the cells. In vitro growth inhibition effect of test compound was assessed by calorimetric or spectrophotometric determination of conversion of MTT into "Formazan blue" by living cells. Remove the supernatant from the plate and add fresh MEM solution and treat with different concentrations of extract or compound appropriately diluted with DMSO. Control group contains only DMSO. In the study, $10,20,25,30$, and $50 \mathrm{ul}$ of the stock solution $(10 \mathrm{mg} / \mathrm{ml}$ prepared in DMSO) were added to respective wells containing $100 \mathrm{ul}$ of the medium. Hence, the final concentrations were $10,20,25,30$, and $50 \mathrm{ug} / \mathrm{ml}$. After $48 \mathrm{~h}$ incubation at $37^{\circ} \mathrm{C}$ in a humidified atmosphere of $5 \% \mathrm{CO}_{2}$, stock solution of MTT was added to each well $(20 \mu \mathrm{l}, 5 \mathrm{mg} /$ $\mathrm{ml}$ in sterile phosphate-buffered saline) for further $4 \mathrm{~h}$ incubation. The supernatant carefully aspirated, the precipitated crystals of “Formazan blue' were solubilized by adding DMSO (100 $\mu \mathrm{l})$ and optical density was measured at wavelength of $570 \mathrm{~nm}$ using LISA plus. The results represent the mean of five readings. The concentration at which the OD of treated cells was reduced by $50 \%$ with respect to the untreated control was determined by below formula.

$$
\% \text { Inhibition }=\frac{100-(\text { Mean abs OD Test sample } \times 100)}{\text { Mean abs OD control }}
$$

To obtain $\mathrm{IC}_{50}$ values, absorbance was measured at $570 \mathrm{~nm}$ in an ELISA multiplate reader.

\section{RESULTS AND DISCUSSION}

Anticancer activity of methanolic extract of $A$. alba on HeLa cell lines $(\mu \mathrm{g})$ 


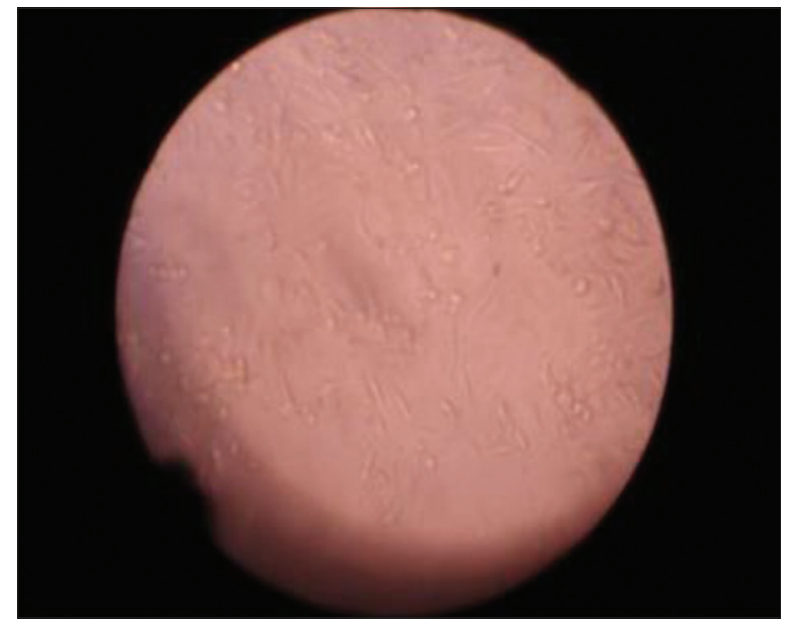

Fig. 3: A.a 10 HeLa cell line

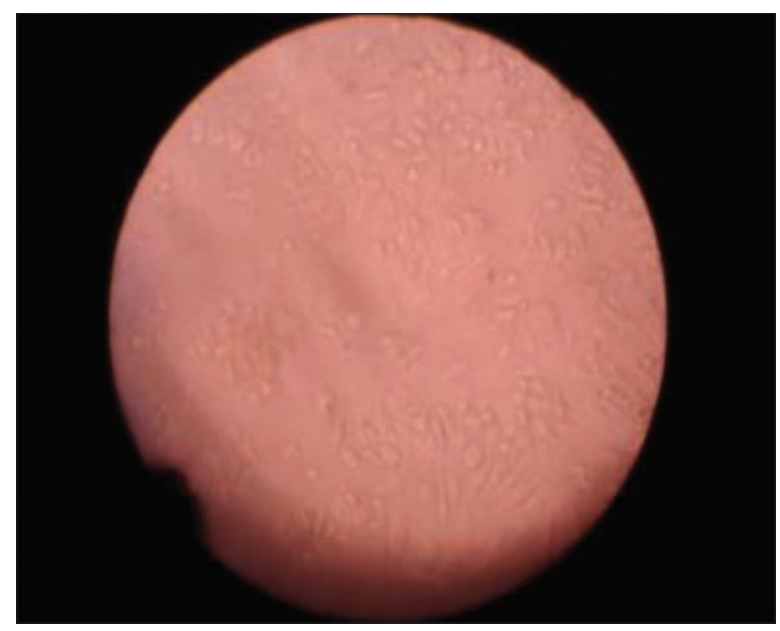

Fig. 4: A.a 20 HeLa cell line

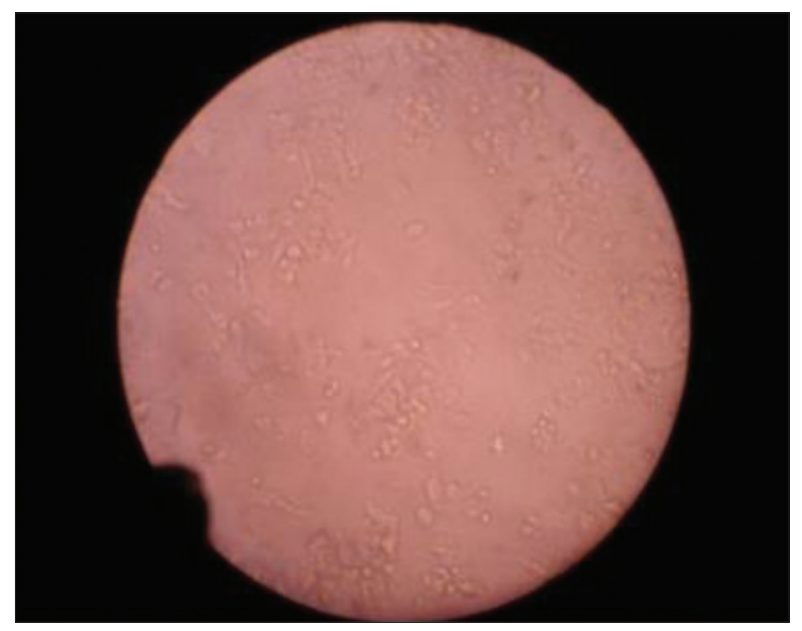

Fig. 5: A.a 25 HeLa cell line



Fig. 6: A.a 30 HeLa cell line

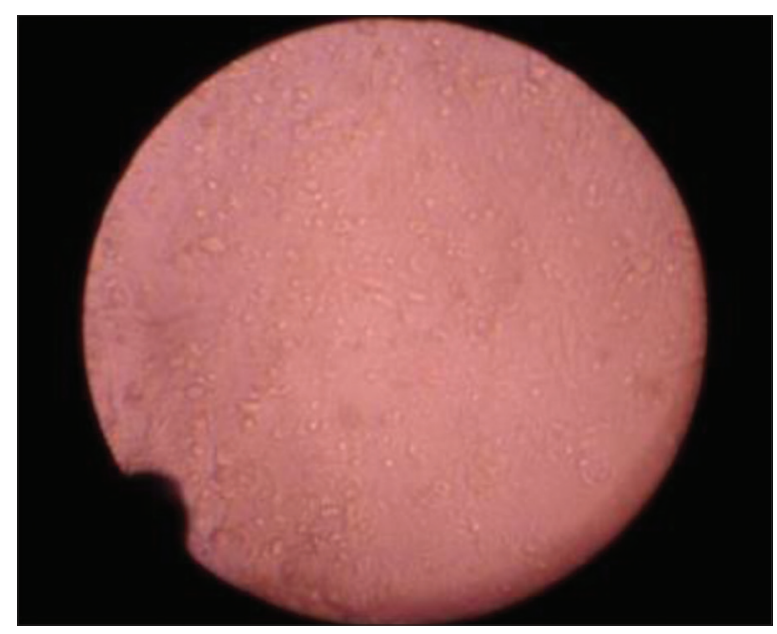

Fig. 7: A.a 50 HeLa cell line

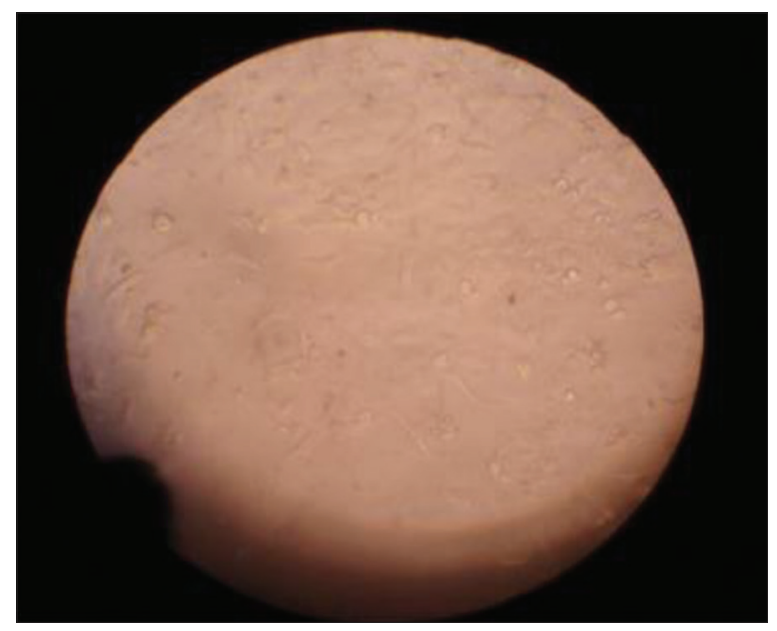

Fig. 8: A.a HeLa control 
Anticancer activity of methanolic extract of $A$. alba MCF-7 cell lines

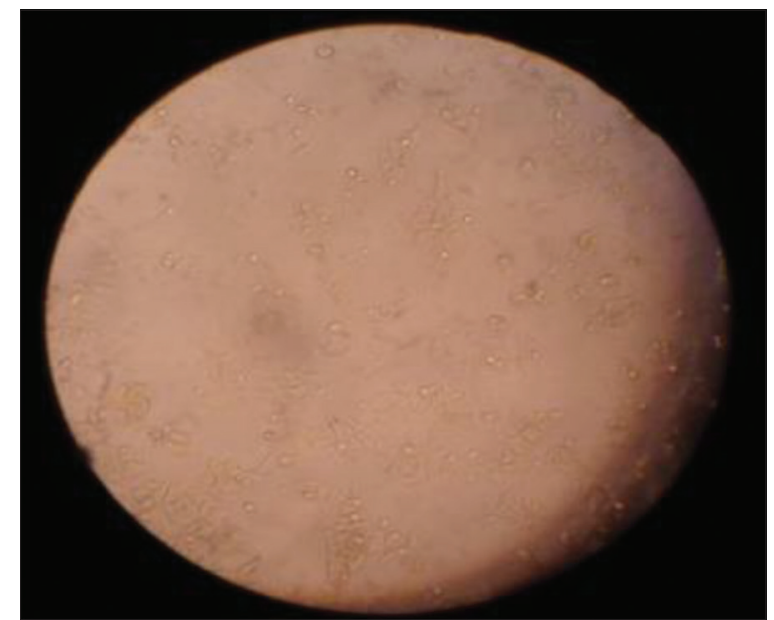

Fig. 9: A.a 10 MCF-7 cell line

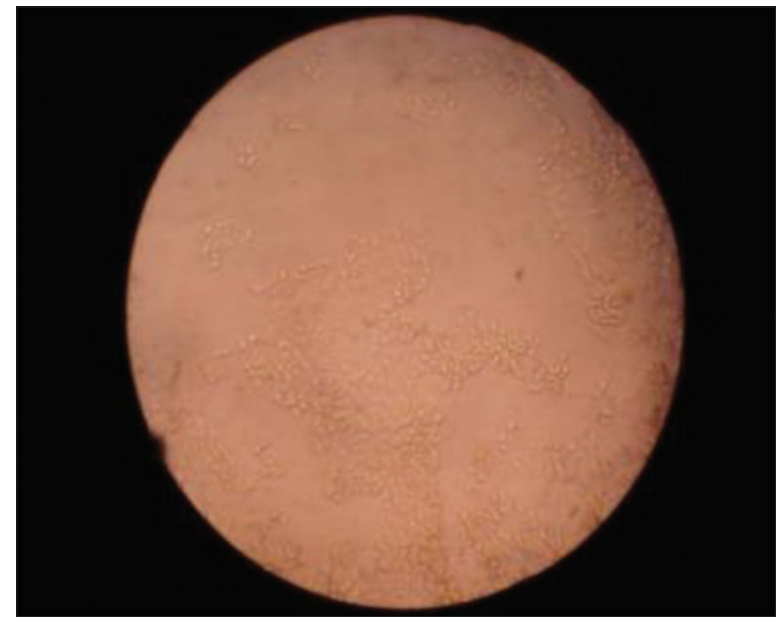

Fig. 10: A.a 20 MCF-7 cell line

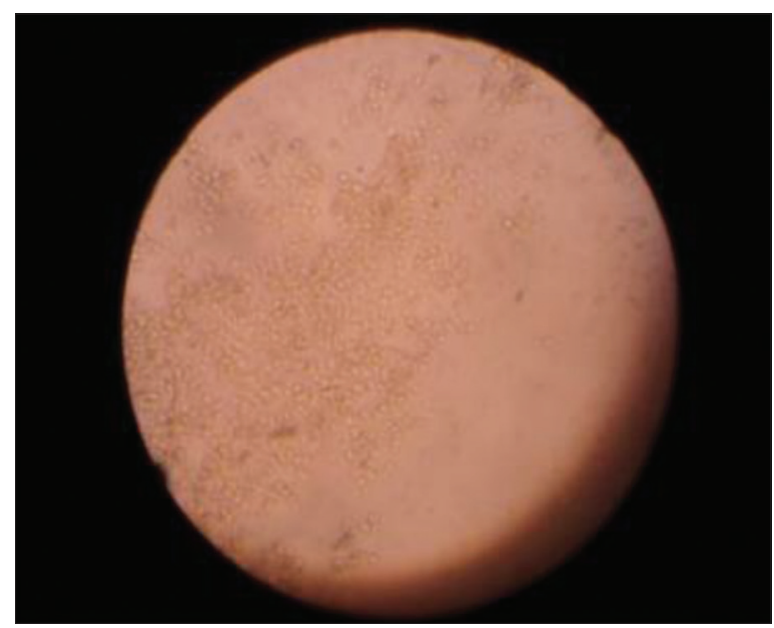

Fig. 11: A.a 25 MCF-7 cell line

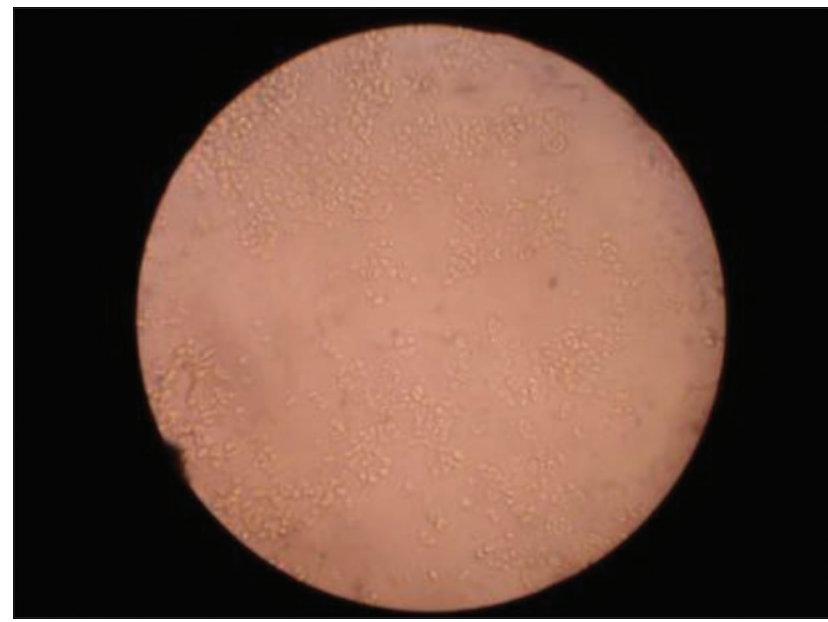

Fig. 12: A.a 30 MCF-7 cell line

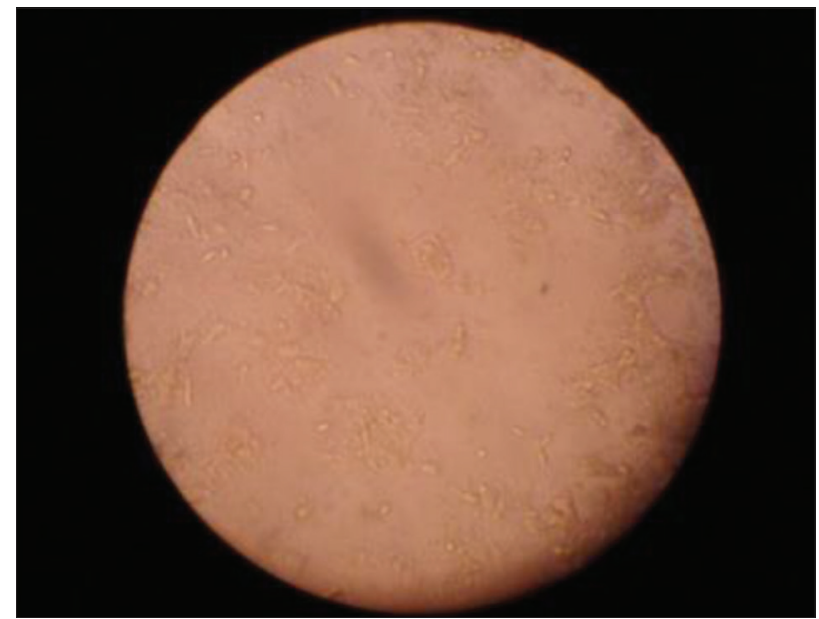

Fig. 13: A.a 50 MCF-7 cell line



Fig. 14: A.a MCF-7 control 
Anticancer activity of cisplatin (standard) on HeLa cell lines ( $\mu \mathrm{g}$ )



Fig. 15: Cisplatin Standard 2.5

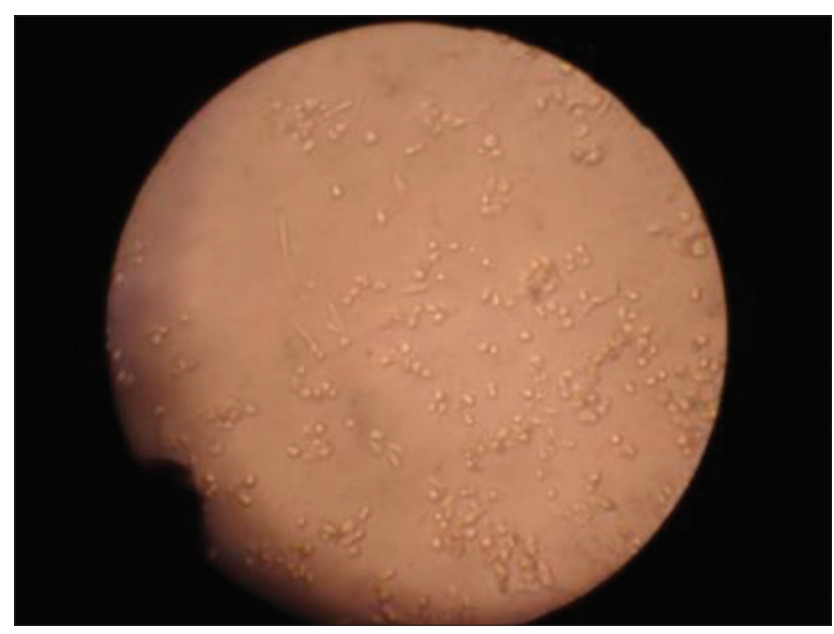

Fig. 16: Cisplatin Standard 5

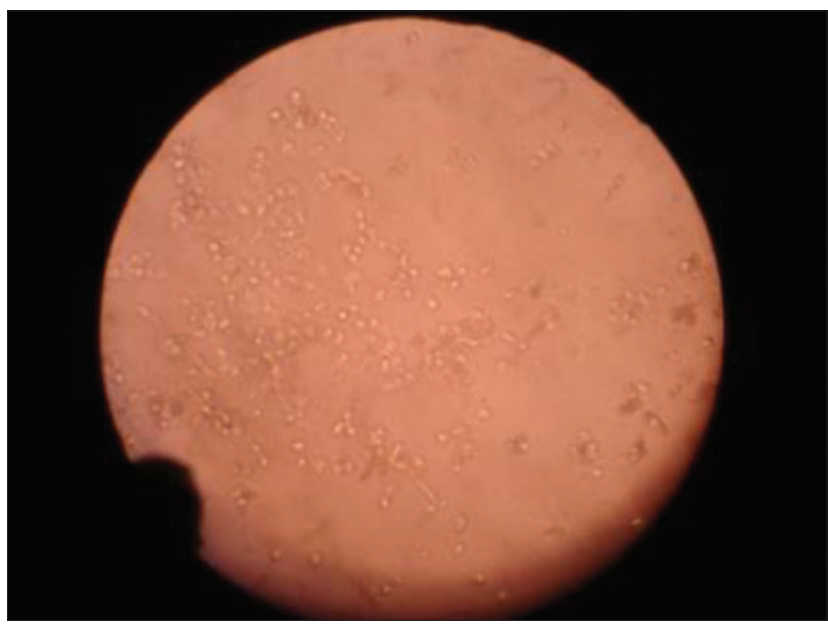

Fig. 17: Cisplatin Standard 7.5

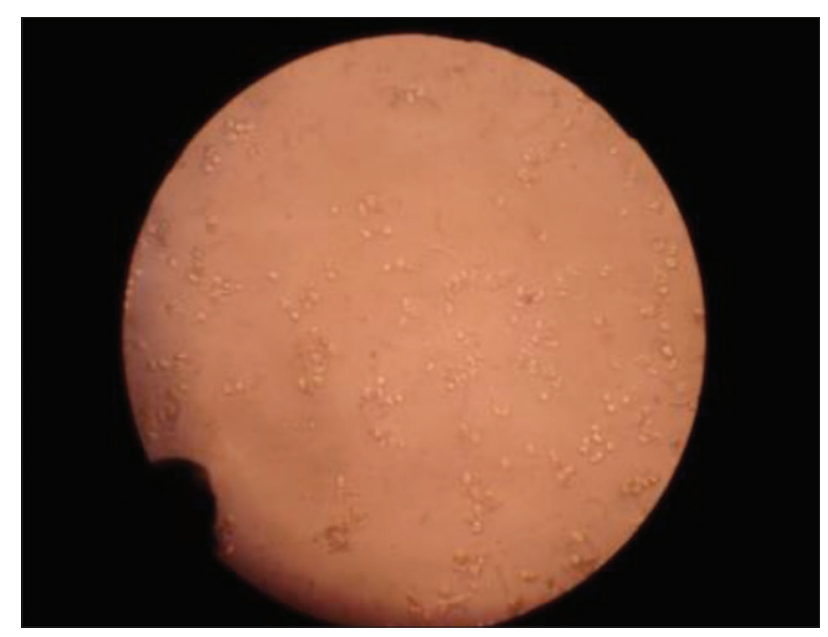

Fig. 18: Cisplatin Standard 10

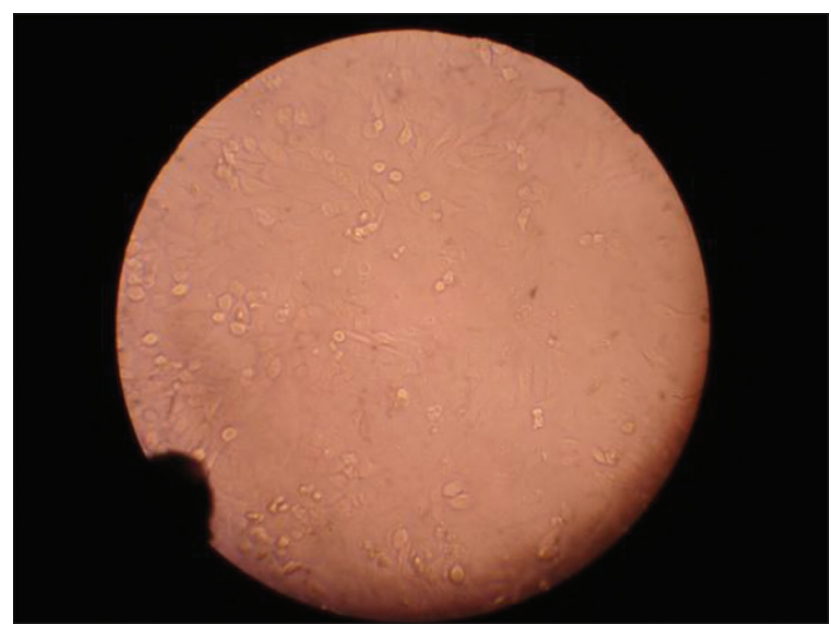

Fig. 19: Cisplatin standard control

Anticancer activity of cisplatin (standard) on MCF-7 cell lines ( $\mu \mathrm{g})$

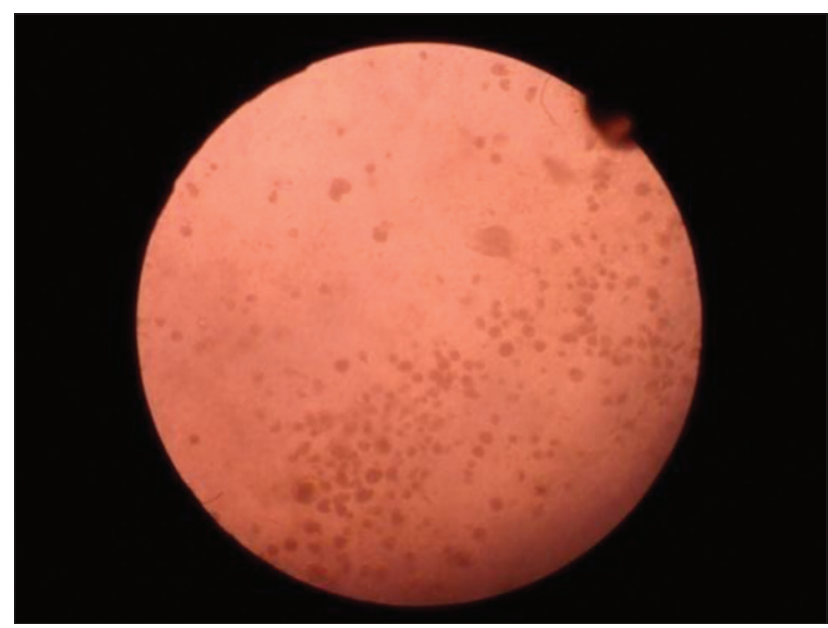

Fig. 20: Cisplatin Standard 2.5 


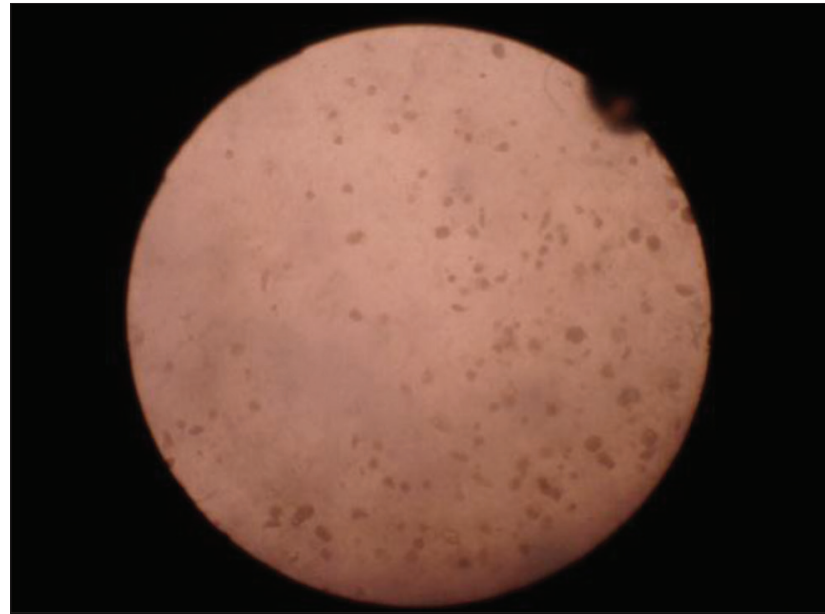

Fig. 21: Cisplatin Standard 5

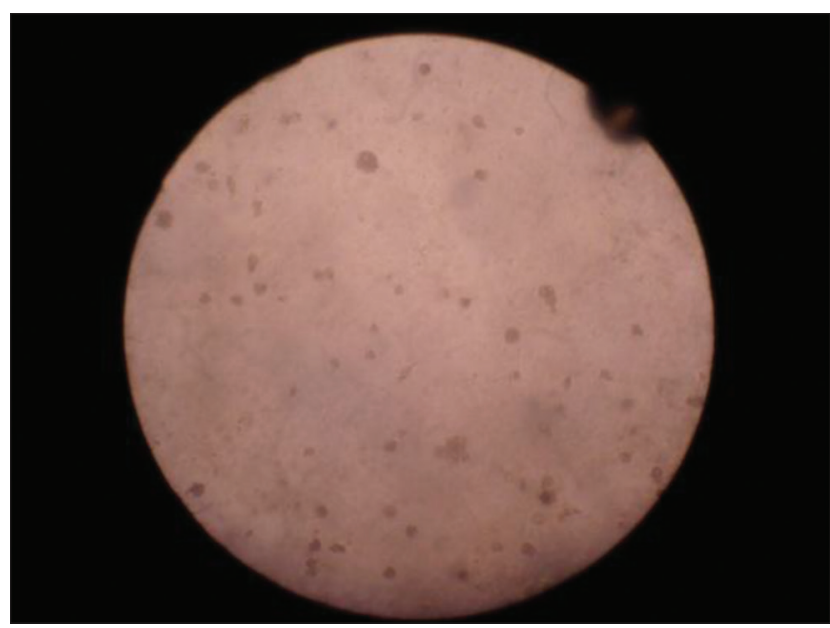

Fig. 22: Cisplatin Standard 7.5

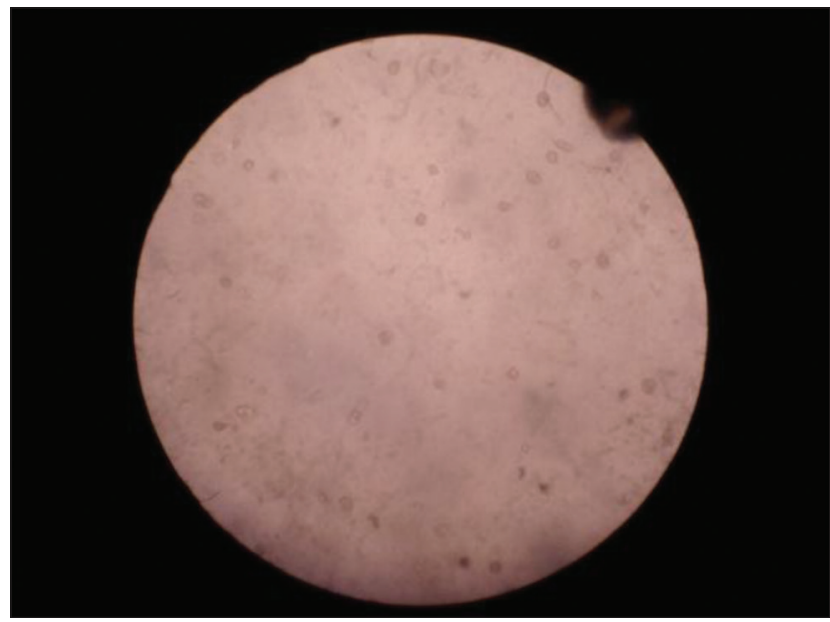

Fig. 23: Cisplatin Standard 10

Figs. 1 and 2 show that anticancer activity of methanolic extract of A. alba was conducted with appropriate positive control (Cisplatin) which yielded results on Hela and MCF-7 cell lines. It was found that the methanolic extract of $A$. alba exhibited more activity against hela cell lines than MCF-7 cell lines. The inhibitory effect of this methanolic extract was observed to be a little bit weaker than that shown by Cisplatin (standard) but was found to be reasonable while inhibiting

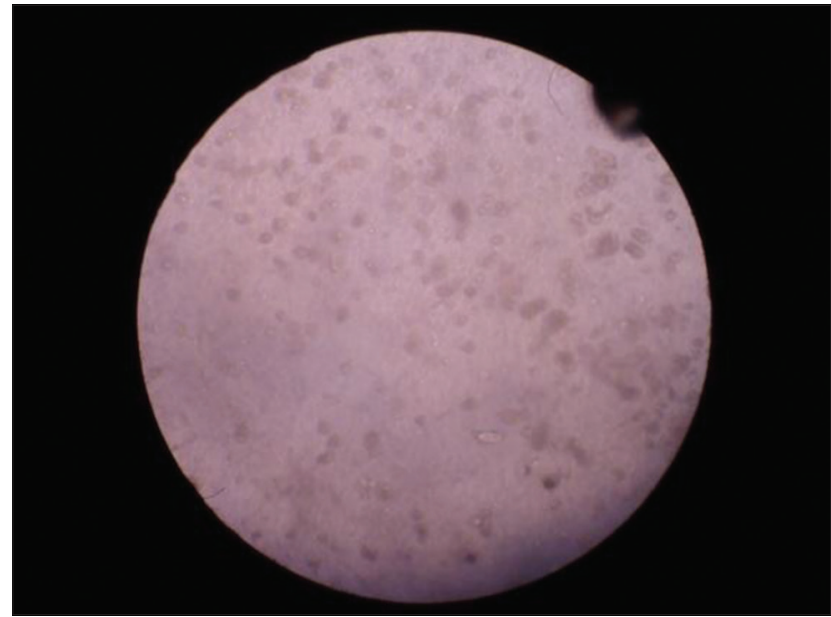

Fig. 24: Cisplatin standard Control

Hela cell lines when compared. The results were shown in tables. From the results, it is clear that IC50 concentration of all fractions is less than or equal to $50 \mu \mathrm{g} / \mathrm{ml}$, that is, the extract is more preferably inhibiting the growth of cancer cells rather than killing the cells as the extract requires very high concentration to kill the cancerous cells when compared to standard drug cisplatin which has IC50 concentration $7.5 \mu \mathrm{g} / \mathrm{ml}$. While coming to growth inhibition, A. alba inhibited the hela cell lines better than the MCF-7 cell lines. The methanolic extract of $A$. alba showed total growth inhibition of $63.21 \%$ and $47.53 \%$ at $50 \mu \mathrm{g} / \mathrm{ml}$ against HeLa and MCF-7 cell lines, respectively, at $33.1 \mu \mathrm{g} / \mathrm{ml}$ against HeLa cell lines. The histopathology studies show an insight to a clearer picture of how the cells growth is controlled. The figures from 3 to 24 depicts the activity of plant on cell lines based on concentration.

\section{CONCLUSION}

The methanolic extract of $A$. alba exhibited more activity against HeLa cell lines than MCF-7 cell lines. The inhibitory effect of this methanolic extract was observed to be inferior to Cisplatin (standard) but was found to be sensible while inhibiting HeLa cell lines on comparison with standard. From the results, it was clear that $\mathrm{IC}_{50}$ concentration of all fractions was less than or equal to $50 \mu \mathrm{g} / \mathrm{ml}$, that is, the extract was comparatively inhibiting the growth of cancer cells at a very low concentration (20 and $50 \mu \mathrm{g} / \mathrm{ml}$ ). A. alba inhibited the HeLa cell lines better than the MCF-7 cell lines. The methanolic extract of $A$. alba inhibited maximum cell growth of $63.21 \%$ and $47.53 \%$ at $50 \mu \mathrm{g} / \mathrm{ml}$ against HeLa and MCF-7 cell lines, respectively. Methanolic extract of $A$. alba showed $\mathrm{IC}_{50}$ concentration of $20 \mu \mathrm{g} / \mathrm{mlfor}$ HeLa and $50 \mu \mathrm{g} / \mathrm{ml}$ for MCF-7 cell lines. Standard drug showed IC50 values at a concentration of $7.5 \mu \mathrm{g} / \mathrm{ml}$.

The $\mathrm{IC}_{50}$ values at low concentrations of plant extract suggests that the plant was considered to be active on cancerous stem cells and the extract is safe with no side effects when compared with cisplatin as the standard drug was synthetic and of high purity and may cause side effects.

Therefore, from the above results it was clear that the plant A. alba was having cytotoxic activity against the HeLa and MCF-7 cell lines and supports the folkloric claims. The histopathology studies show an insight to a clearer picture of how the cells growth is controlled. The outcome of the present study encourages to carry out further studies to be extended for other cell lines and in vivo cytotoxicity investigation required to identify anticancer activity. This also enabled to go further into the molecular level to identify different compounds present in the plant source.

\section{ACKNOWLEDGMENT}

The author would like to acknowledge Andhra University college of Pharmaceutical Sciences, Andhra University, Visakhapatnam, for providing their lab facilities and library. 


\section{AUTHORS CONTRIBUTION}

R A Zerubabel Michael designed and performed the research experiment. The write up of the article and corrections were done by the author.

\section{CONFLICTS OF INTEREST}

The author declares no conflict of interest.

\section{AUTHOR FUNDING}

The author has not received any funding from any agency.

\section{REFERENCES}

1. Dikshit A, Shahi SK, Pandey KP, Patra M, Shukla AC. Aromatic plants: A source of natural chemo-therapeutants. Natl Acad Sci Lett 2004;27:145-64

2. Larkin T. Herbs are Often More Toxic than Magical. United States: Department of Health and Human Services, Public Health Service, Food and Drug Administration; 1984.

3. Newman DJ, Cragg GM, Snader KM. The influence of natural products upon drug discovery. Nat Prod Rep 2000;17:215-34.

4. Newman DJ, Cragg GM, Snader KM. Natural products as sources of new drugs over the period 1981-2002. J Nat Prod 2003;66:1022-37.

5. Abu-Dahab R, Afifi F. Antiproliferative activity of selected medicinal plants of Jordan against a breast adenocarcinoma cell line (MCF7). Sci Pharm 2007;75:121-46.
6. Priya K, Krishnakumari S, Vijayakumar M. Cyathula prostrata: A potent source of anticancer agent against daltons ascites in Swiss albino mice. Asian Pac J Trop Med 2013;6:776-9.

7. Alison MR. Cancer. Encyclopedia of Life Sciences. London: Nature Publishing Group; 2001.

8. Wu J, Xiao Q, Xu J, Li MY, Pan JY, Yang MH. Natural products from true mangrove flora: Source, chemistry and bioactivities. Nat Prod Rep 2008;25:955-81.

9. Jain R, Jain SK. Screening of in vitro cytotoxic activity of some medicinal plants used traditionally to treat cancer in Chhattisgarh state, India. Asian Pac J Trop Biomed 2011;1:S147-50.

10. Mulla SK, Swamy PA. Anticancer activity of ethanol and polyphenol extracts of Portulaca quadrifida Linn. On human colon cancer cell lines. Int J Pharm Biosci 2012;3:488-98.

11. Duke N, Ball M, Ellison J. Factors influencing biodiversity and distributional gradients in mangroves. Glob Ecol Biogeogr Lett 1998; 7:27-47.

12. Kathiresan K. Biodiversity of Mangrove Ecosystems, Proceedings of Mangrove Workshop. Gujarat, India: GEER Foundation; 2008.

13. Tomlinson PB. The Botany of Mangroves. London: Cambridge University Press; 1986.

14. Kathiresan K, Ramanathan T. Medicinal Plants of Parangipettai Coast. Chennai: Annamalai University; 1997.

15. Mosmann T. Rapid colorimetric assay for cellular growth and survival: Application to proliferation and cytotoxicity assays. J Immunol Methods 1983;65:55-63.

16. Doyle A, Griffiths JB, editors. Cell and Tissue Culture for Medical Research. United States: Wiley; 2000. 